basal hay and grain diet with $90 \mathrm{~g}$ rumen degradable crude protein in the DM, was not significantly related to any increase in nitrogen accretion. Fish meal addition, on the other hand, gave a significant curve-linear increase in nitrogen retention in milk. Optimal level of fish meal inclusion was depended on fish meal quality, but was in the range 10 to $12 \%$ in the concentrate.

Key words: Feed intake, nitrogen retention, goat, urea, fish meal.

\title{
Effect of addition of animal or vegetable fat to a hay based diet on digestibility and nitrogen balance in the lactating goat
}

\section{R. DACCORD}

\author{
Swiss Federal Research Station for Animal Production, Grangeneuve, CH-1725 Posieux
}

At the beginning of lactation, the high producing ruminant is subjected to the energy deficiency. In production systems where forage intake is predominant like in Switzerland, energy deficiency can be coupled with a low intake of fatty acids, particularly when hay rations are complemented with fodder beets. Supplementation of such diets with animal or vegetable fat was studied in a balance experiment performed in goats.

A total of 15 lactating goats were assigned to three diets based on hay, fodder beets and on the following concentrates: $\mathrm{A}=$ cereals and soybean meal $(16 \%), \mathrm{B}=$ as $\mathrm{A}$, but with an addition of $4 \%$ micronized animal fat, $\mathrm{C}=$ as $\mathrm{A}$, but replacing soybean meal by extruded soybean $(20 \%)$. Concentrates were iso-nitrogenous, containing $2.0,5.9,6.0 \%$ crude fat in the DM respectively. All diets were given ad libitum. On a net energy basis, they were made up of $50 \%$ hay, $25 \%$ fodder beets and $25 \%$ concentrates.

Goats fed diet $\mathrm{A}$ had the highest intake $(\mathrm{kg} / \mathrm{day}: \mathrm{A}=2.152 ; \mathrm{B}=2.061 ; \mathrm{C}=2.027$; $s_{\bar{x}}=0.114$ ). Digestibility of all the main nutrients except crude fat was lower with diet $B$. Digestibility of organic matter, crude protein and crude fat was higher with diet $\mathrm{C}$. The fibre fraction had the highest digestibility with diet $\mathrm{A}\left(\mathrm{A}=62.0 ; \mathrm{B}=59.1 ; \mathrm{C}=60.7 ; \mathrm{s}_{\bar{x}}=1.2\right)$. Diet $\mathrm{C}$ decreased the proportion of faecal $\mathrm{N}$ and increased the proportion of urine $\mathrm{N}$ ( $\mathrm{N}$-urine, \% $\mathrm{N}$ intake: $\left.\mathrm{A}=25.8^{\mathrm{ab}} ; \mathrm{B}=22.2^{\mathrm{a}} ; \mathrm{C}=29.7^{\mathrm{b}} ; \mathrm{P}<0.05\right)$. Diet $\mathrm{B}$ had the best efficiency of $\mathrm{N}$ utilization. The main mineral balances were not affected by the diet.

Production of $3 \%$ fat corrected milk was lowest with diet $\mathrm{C}(\mathrm{kg} / \mathrm{day}: \mathrm{A}=3.58 ; \mathrm{B}=3.73$; $\mathrm{C}=3.15, \mathrm{~s}_{\overline{\mathrm{x}}}=0.22$ ). Both diets with higher fat content increased the protein and fat content of milk (protein $\%: \mathrm{A}=2.67^{\mathrm{a}} ; \mathrm{B}=2.81^{\mathrm{b}} ; \mathrm{C}=2.86^{\mathrm{b}} ; \mathrm{P}<0.05 ;$ fat $\%: \mathrm{A}=2.83 ; \mathrm{B}=3.20$; $\mathrm{C}=3.28$ ). These diets decreased the content of middle chain fatty acids and increased that of long chain fatty acids.

The dietary treatments had no significant effect on the concentration of blood metabolites and enzymes, except for cholesterol, whose level was increased with fat supplements.

In conclusion, addition of a limited amount of a good quality fat (of animal or vegetable origin) to a forage-based diet can be a valuable solution for increasing concentrated energy and fatty acids in the diet of high producing ruminants.

Key words: Fat, nitrogen balance, digestibility, goat.

\section{Effect of a high dietary potassium content on Mg-, K- and Na-metabolism in the lactating goat}

\section{J. KESSLER}

Swiss Federal Research Station for Animal Production, Grangeneuve, CH-1725 Posieux

Only fragmentary information on K-requirement of goats is available. As in sheep the net minimum endogenous requirement can be fixed at $20 \mathrm{mg} \mathrm{K} / \mathrm{kg}$ live weight. The net requirement 